\title{
The Cycle of Trauma in The Love of the Last Tycoon: A Western
}

\author{
Thi Huong Giang Bui (Corresponding author) \\ Department of English Literature \\ Fukuoka Women's University, 1-1-1 Kasumigaoka, Higashiku, \\ Fukuoka, Japan 813-8529.
}

Received: 19-12-2013

doi:10.7575/aiac.ijclts.v.2n.2p.6
Accepted: 10-1- 2014

Published: 01-04-2014

\begin{abstract}
My present study deals with the F. Scott. Fitzgerald's male character, Monroe Stahr, in The Love of the Last Tycoon: A Western, which was first edited by Edmund Wilson and published in 1941, entitled "The Last Tycoon", one year after Fitzgerald's death. This novel can be seen as the resolution of Monroe Stahr's trauma, whose desire is to win a beautiful woman after the loss of his beloved wife. Various literary studies, such as trauma theory, psychoanalytic approach, historical and biographical approach will be used to analyze the psychological loss and the varieties of traumatic continuation of the protagonist of the novel. It focuses on the thesis: Stahr has suffered traumatic losses of his wife and his girlfriend, and these experiences change his character fundamentally. The paper continues with the discussion using the extracts from the novel to exhibit the effects of Stahr's trauma.
\end{abstract}

Keywords: The Love of the Last Tycoon, trauma, idealized love, loss, death

The time between writing Tender is the Night and The Love of the Last Tycoon was the darkest in Fitzgerald's life. Although Fitzgerald spent a great length of time on Tender is the Night, he received only lukewarm critical reviews that left him emotionally bankrupt and the novel was considered to be "a failure in terms of Fitzgerald's expectations" (Bruccoli 363). Most obviously, however, Fitzgerald no longer enjoyed the glamorous times he had previously experienced since The Great Gatsby was published. In the more than ten years since Fitzgerald had been seen as an icon of the Jazz Age, he had come to be regarded as somewhat a poor old man on account of the downfall of his literary career. Besides, Fitzgerald had to face enormous debts, the incurably schizophrenic Zelda, and Scottie's education.

Fitzgerald, therefore, was very aware of the changes in his career and of the need to find a new motif for the next novel to retrieve his reputation and popularity. In a letter to Maxwell Perkins to announce this novel, Fitzgerald confessed that he was "by no means sure that I will ever be a popular writer again" and "this much of the book, however, should be as fair a test as any" (Bruccoli 420). Additionally, in a letter to Kenneth Littauer, Colliers fiction editor, Fitzgerald suggests that the new novel "is absolutely true to Hollywood" and he is trying "to open up a new well, a new vein" (Bruccoli 402). Hence, it may be supposed that Fitzgerald took a gamble on the new novel to win back the glamour of his heyday, hoping that the new novel could help him solve his personal matters.

Hollywood, for this reason, evidently became a means for this purpose, since according to Addison, "Hollywood became established - not only as a center of film production, but also as a cultural institution that valued conspicuous consumption, sexual display, physical culture, and youth" (Addison 6). Consequently, Fitzgerald took an adventurous trip there in an attempt to achieve the American Dream, as in his eyes Hollywood represented the last frontier. Addison also points out that "the elements of America's New World myth - inventiveness, youth, adventure, energy-were concentrated in the fresh, lively, popular art form produced in America's last frontier: Hollywood" (15). Moreover, "Fitzgerald had once written 'There are no second acts in American lives'. But he had gone to Hollywood to prove himself wrong" (Stavola 69). Fitzgerald also wrote in a letter to his only daughter, Scottie, in 1937 on his way to Hollywood, that this was his "third Hollywood venture" (Bruccoli 330) and he felt "certain excitement". Fitzgerald, of course, did not want to be a failure again in the "New World" Hollywood, which meant that he had to re-invent himself to match that society. That society had brought Fitzgerald a chance to start his last novel. As Pelzer points out, the novel is truly "a story of the West, of the frontier, of aspiration. Stahr embodies the last of the American pioneers. He is the immigrant son of people who risked all to attain their dream of success. When they found their passage blocked, they simply moved on, out into the vast American western frontier of perpetual promise. That frontier eventually became a state of mind - an expression of desire, a belief in possibility - and its promise beckons still, in the ultimate dream factory at the farthest reaches of the western frontier, Hollywood" (Pelzer 139).

Hollywood, ironically, did not match Fitzgerald's final expectations, and Fitzgerald did not succeed in seizing that chance. Although Fitzgerald "was at the best studio in Hollywood" (Bruccoli 422) and his salary was roughly \$1,000 a week, which placed him among the highest-paid movie writers, he "had no heart for" it (Bruccoli 422). As a result, "Fitzgerald's contribution on the movie [A Yank at Oxford] was not substantial enough to earn him a screen credit - the gauge by which a writer's success was measured" (Bruccoli 424). Fitzgerald got his only screen credit for the Three Comrades script. That is why in December 1938 his MGM contract was not renewed and Fitzgerald had to face money problems again. Fitzgerald was even fired for drunkenness while he worked on Winter Carnival at Dartmouth College 
in 1939. Aaron Latham also indicates that "Hollywood had Scott Fitzgerald down as a drunk [...] and there were recurrent bouts during Fitzgerald's Hollywood years, from 1937 to his death in 1940, when all his days seemed to be caught up in a drunken party which would not end, when he went on making a fool of himself day after day. Toward the end he couldn't find work" (vii). As a result, Fitzgerald could not "prove himself wrong" as he failed in his dream of restoring his fame and reputation, and suffered a fatal heart attack in 1940 while he was writing The Love of the Last Tycoon.

Fitzgerald never became a successful screenwriter may have resulted partly from the fact that he "lacked the necessary autonomy to unleash his talents" (Pelzer 132), but Hollywood obviously provided him with the backdrop and a new theme for his last novel which was "about the last American frontier, where immigrants and sons of immigrants pursued and defined the American dream. It is appropriate that these tycoons made movie westerns: they too were pioneers" (Bruccoli xvii). In addition, The Love of the Last Tycoon is considered an unfinished masterpiece by many. Edmund Wilson asserts that it is "Fitzgerald's most mature piece of work" and "far and away the best novel we have had about Hollywood" (Bruccoli lxxv). John Chamberlain's note about Fitzgerald's Stahr also points out that "this man is not only a movie man: he is the talented American business executive in any sphere" (Bruccoli lxxvi). On the other hand, it is supposed "to be a tragic novel" (Stavola 69) of a heroic producer who was committed to increasing the artistic level of the developing film industry. Consequently, we can say that the novel exhibits the tragic life of a very masculine and successful man in Hollywood. As Pelzer points out, "Fitzgerald dissects the Hollywood film industry, that purveyor of myths and dreams and that last western frontier, to expose the debased, materialistic power that ultimately destroys the icon of American success - the self-made man" (131). Moreover, "Fitzgerald even manages to bridge the gap between Stahr the wary [sic] and disenchanted man of experience and Stahr the passionate lover. As a matter of fact, that disjunction is close to the center of interest in the book, which is concerned with a man, like Fitzgerald himself, who had loved and lost and who, without ever recovering from the jolt, becomes a different person" (Fahey 122). That loss clearly has fundamentally changed Stahr since the loss of his dead wife, leading to the emotional stress and his identity disorder.

Taking this historical and critical background into account, I would argue that it is desirable to examine The Love of the Last Tycoon and its hero using the theoretical framework of trauma theory, the psychoanalytic approach and gender theory, proposing a traumatic loss suffered by the hero. It is here that we can find effects of the traumatic loss experienced by a truly masculine hero, Monroe Starh, when he feels miserable over the death of his wife and Kathleen, his lover. Moreover, "his continued love of life, his daily defiance of death, and his victory over the ghosts of the past, as evinced in his love for Kathleen, deepens the pathos to tragedy" (Fahey 122). Although in The Love of the Last Tycoon he has managed to resolve many of the gender anxieties of the previous novels, Fitzgerald endeavored to recycle the motif that he used successfully in his previous novels, the death of the American Dream. The Love of the Last Tycoon, therefore, can be seen as a continuation of Fitzgerald's traumatic fictional narratives exhibiting the losses of idealized women, the failure of artistic commitments and the death of the hero. "In Monroe Stahr, Fitzgerald embodies the failure of a man ambitious for power and desirous of love to humanize his society enough to live in fulfillment himself" (Callahan 210), and this book is about "the struggle to abandon illusions and enter into life" (Callahan 203).

It is significant, however, that Fitzgerald in Hollywood differed widely from the man of the 1920s who had been an icon of the Jazz generation. Fitzgerald was no longer a celebrity in New York City. He became a traumatized old man burdened with debts. "When he went to work for M-G-M, he was more than $\$ 22,000$ in debt: $\$ 12,511.69$ to Ober; $\$ 1,150$ to Perkins; and at least another $\$ 9,000$ to Scribners in loans and advances. The value of his life insurance policy had been reduced to $\$ 30,000$. He was behind in the payments to Highland Hospital, where the annual charges for Zelda were \$6,780 in 1938" (Bruccoli 419). It is likely that he had no choice but to work hard to pay these debts and support his family, especially the charges for Zelda's treatment. Nevertheless, Fitzgerald could not overcome his money troubles and "he still owed Scribners more than \$5,000 at his death" (Bruccoli 420). At the time of starting his novel, 1939, Fitzgerald wrote a letter to Zelda and said "I'm almost penniless" (Bruccoli 412). Therefore, this novel must be seen partly as Fitzgerald's attempt to solve the money problems that had haunted him in the final years of his life.

What is more, Fitzgerald's relationship with Zelda became worse and worse. In a letter to Dr. Carroll in 1939 , Fitzgerald wrote "She [Zelda] has cost me everything a woman can cost a man-his health, his work, his money" (Bruccoli 418). Zelda's mental illness had progressed and she spent most of her time in asylums or in the care of her mother and sisters. Their interactions were limited by her illness and his work. Therefore, the void left by the absence of Zelda from his life left room for someone new. In the summer of 1937 Fitzgerald met Sheila Graham, a young gossip columnist, who would replace Zelda as Fitzgerald's companion. Though Graham brought a new life for Fitzgerald at the very time he was writing "I just loved you-you brought me everything" or "now for over two years your image is everywhere [...] You are the finest. You are something all by yourself...I will have my last time with you, though you won't be there...I love you utterly and completely" (Bruccoli 421-422), nevertheless, Fitzgerald, like Monroe Stahr, was still traumatized by the fact that he had lost Zelda, who seemed to be his idealized love for most of his life. Fitzgerald wrote openly of death to Graham: "I want to die, Sheila, and in my own way. I used to have my daughter and my poor lost Zelda" (Bruccoli 421-422). Fitzgerald "went back to Hollywood in July, 1937, to fulfill his responsibilities to Zelda, now permanently gone from him, and to his daughter; but he moved west also to establish an independent attitude toward the past so that he could, when the opportunity presented itself, live and write in a new context" (Callahan 200-201). 
One other significant detail of the novel is that its hero, Monroe Stahr, is a creative reflection of the real Hollywood executive, Irving Thalberg, as Fitzgerald once acknowledged. Fitzgerald met Irving Thalberg, who was considered the "boy wonder" of the movie industry in January 1927. Irving Thalberg was "head of production at Universal when he was twenty and died in 1936 at thirty-seven" (Bruccoli 462). Fitzgerald once confessed that "Thalberg has always fascinated me. His peculiar charm, his extraordinary good looks, his bountiful success, the tragic end of his great adventure. The events I have built around him are fiction, but all of them are things which might very well have happened, and I am pretty sure that I saw deep enough into the character of the man so that his reactions are authentically what they would have been in life. So much so that he may be recognized — but it will also be recognized that no single fact is actually true. For example, in my story he is unmarried or a widower, leaving out completely any complication with Norma" (Bruccoli 409). As clearly seen from the novel, Stahr, a powerful producer, cannot escape from the loss of his beloved. As a result, the outcome of his conflict is a depressed yearning for the lost person, wandering through life to find the reflection of his dead wife. Fitzgerald's most masculine hero, Stahr, like Fitzgerald's own creative figure, at last meets a tragic end indeed.

In a letter to Norma Shearer, Thalberg's wife, Fitzgerald wrote "though the story is purely imaginary perhaps you could see it as an attempt to preserve something of Irving. My own impression shortly recorded but very dazzling in its effect on me, inspired the best part of the character of Stahr [...] I invented a tragic story and Irving's life was, of course, not tragic except his struggle against ill health, because no one has ever written a tragedy about Hollywood" (Bruccoli 462). Similarly, Norma reported that "Monroe Stahr was not at all like her husband" (Bruccoli 462). It is not difficult to understand Norma's objection because Fitzgerald definitely "had not attempted to write a biographical novel about Irving Thalberg" (Bruccoli 462). However, Stahr can be seen as the most complete hero in Fitzgerald's literary career with his inevitably tragic fate.

As Callahan points out, "Fitzgerald embodied in his tissues and nervous system the fluid polarities of American experience: success and failure, illusion and disillusion, dream and nightmare" (Callahan 1). As a result, Stahr is the most convincing character in Fitzgerald's literary career. Monroe Stahr, like Fitzgerald's other heroes in his previous novels, endeavors to pursue the American dream. Specifically, "Monroe Stahr, like Jay Gatsby, is an idealist destroyed by the corruption of his own dream. Like Gatsby, Stahr is a self-made man. He rises from the obscurity of a Jewish ghetto in the Bronx, New York, to become the ultimate purveyor of dreams. Indeed, he embodies the American Dream of Success, and he believes in the system that has enabled his self-creation" (Pelzer 139). Clearly, Stahr partly achieves his dream when he becomes a very powerful and successful executive. However, "without contact and love, it seems a man must parcel himself out in small perishable pieces until there is nothing left for any action or any relationship. Stahr's tragedy is that he acts as if the legend about himself as irreplaceable executive were all fact and no rhetoric. Desire for power and a sense of responsibility for his culture have led him away from the intimate needs of his personality" (Callahan 210). Stahr is also destroyed by his obsessive pursuit of happiness with a woman who was a mirror image of his dead wife. Stahr's fate turns out to be Gatsby's, as they both lose their love and end up dying, suggesting a traumatic continuation in Fitzgerald's last novel. Obviously, Stahr's tragic fate, if one adopts critical conception from LaCapra and Caruth, is concerned with the unspeakable loss of his wife. Even though he transfers the love for his wife to another woman, he cannot heal the scar in his mind and recover from this trauma, thus showing his split identity in life.

As in The Great Gatsby, Fitzgerald uses the voice of first-person narrator to tell the story. Fitzgerald writes at one point in the novel that "this is Cecelia taking up the narrative in person" (77). In a 1939 letter to Kenneth Littauer, Fitzgerald revealed that "The Story occurs during four or five months in the year 1935. It is told by Cecelia, the daughter of a producer named Bradogue in Hollywood. Cecelia is a pretty, modern girl neither good nor bad, tremendously human" (Bruccoli 408). The reason Fitzgerald chose Cecelia as the narrator is because "I think I know exactly how such a person would react to my story. She is of the movies but not in them. She probably was born the day The Birth of a Nation was previewed and Rudolf Valentino came to her fifth birthday party. So she is, all at once, intelligent, cynical but understanding and kindly toward the people, great or small, who are of Hollywood", as he admitted (Bruccoli 409). Similarly, as the narrator, Cecelia Brady observes that "though I haven't ever been on the screen I was brought up in pictures" (3). It seems that Cecelia is a perfect narrator for the story because she can genuinely understand the Hollywood community. It is she who "sees the events in the story of Monroe Stahr, a great motion-picture producer, [and] tells with adolescent anguish of Stahr's double devotion: to work and to memory of his dead wife Minna" (Fahey 121). Stahr, therefore, becomes a vivid masculine figure in the loving view of the beholder, Cecelia, who has long had illusions about him and idealizes him in every way.

Stahr works in the studio, which can be considered as a "fairyland" and "the torn picture books of childhood, like fragments of stories dancing in an open fire" (25). Hollywood, on the other hand, seems to be strange and weird to ordinary people. As Cecelia comments, "some of the English teachers who pretended an indifference to Hollywood or its products really hated it. Hated it way down deep as a thread to their existence" (3). Hollywood is like a mysterious world: "you can take Hollywood for granted like I did, or you can dismiss it with the contempt we reserve for what we don't understand. It can be understood too, but only dimly and in flashes. Not half a dozen men have ever been able to keep the whole equation of pictures in their heads. And perhaps the closest a woman can come to the set-up is to try and understand one of those men" (3). Stahr, therefore, can be regarded as a legend in this mysterious land, showing both his contribution to this place and the power of his work. 
Structurally and figuratively, Stahr has a "symbolic status as representative American hero" and "he is the Andrew Carnegie, the Cornelius Vanderbilt, the John Jacob Astor of his day" (Pelzer 139). Stahr's life is a truly traditional ragsto-riches story which derives from a foundational American myth. Like Jay Gatsby, Stahr's childhood and education remain mysterious. According to the narrator, "though Stahr's education was founded on nothing more than a nightschool course in stenography, he had a long time ago run ahead through trackless wastes of perception into fields where very few men were able to follow him" (18). According to Pelzer, "Stahr has climbed from poverty and obscurity by a combination of hard work, shrewd instincts, and an utterly unflinching belief in his inevitable success" (Pelzer 139) and that is why Stahr, as the narrator reveals, "had flown up very high to see, on strong wings when he was young. And while he was up there he had looked on all the kingdoms, with the kind of eyes that can stare straight into the sun" (20). Besides, Stahr is also described as an angel "beating his wings tenaciously - finally frantically — and keeping on beating them he had stayed up there longer than most of us, and then, remembering all he had seen from his great height of how things were, he had settled gradually on earth" (20). In addition, Stahr "saw a new way of measuring our jerky hopes and graceful rogueries and awkward sorrows, and that he came here from choice to be with us to the end" (21). It is clear that after working hard, Stahr becomes "a money man among money men" (45), having lunch with Danish Prince Agge (44) and receives a phone call alleged to be from the president of the United States (83).

Additionally, Stahr exhibits his powers not only through his eyes but also through his work. He has been depicted as "a marker in industry like Edison and Lumiere and Griffith and Chaplin. He led pictures way up past the range and power of the theatre, reaching a sort of golden age before the censorship in 1933" (28). In a conference with writers Rose Meloney and Wylie White, supervisor Joe Rienmund, and director John Broaca, Stahr shows his dissatisfaction with a script scheduled for production and offers suggestion for improvement. Stahr also instructs the conferees of what kind of story could attract the public, and "the story we bought had shine and glow-it was a happy story" (39). In order to improve the film, Stahr is willing to replace director Red Ridingwood because Red cannot handle the star actress in his movie. Stahr tells Prince Agge that "I'm the unity". By that he means he wants to unite the whole studio together. Stahr believes that he can handle his studio and unite everyone to produce the best art forms. A powerful producer, Stahr, however, exhibits the insecurity of an ego injury as the loss of his wife becomes a haunted longing: she is projected, imagined and transferred to a new existence.

The narrator sees Stahr's power through "worshipping eyes" (Callahan 203). She thinks that "his dark eyes took me in, and I wondered what they would look like if he fell in love. They were kind, aloof and, though they often reasoned with you gently, somewhat superior" (15) and "I never dared look quite away from him or quite at him, unless I had something important to say - and I knew he affected many other people in the same manner" (15). In a flood, when Stahr "took a tentative step to see if the weakness had gone out of his knees [...] men began streaming by him —every second one glancing at him smiling speaking Hello Monroe...Hello Mr. Stahr...wet night Mr. Stahr...Monroe...Monroe...Stahr...Stahr....Stahr" (27). At that moment, he is "like the Emperor and the Old Guard. There is no world so but it has its heroes and Stahr was the hero" (27). However, Stahr seems to be a lonely emperor in his small world, as the trauma of his loss of his beloved has overwhelmed his mind. In reality, Stahr wants to hide everything that reminds him of his dead wife, but he seems not to be able to recover from the pain of the past.

Stahr does not love Cecelia but instead finds a woman who looks like his dead wife. Kathleen Moore can be seen the object of Stahr's romantic pursuit. 'Since Kathleen resembles Minna, Stahr's dead wife, the new is not completely new. And obviously the different person who finds Kathleen on a studio lot is still very much the same man as the one who loved Minna" (Fahey 122). It seems that "a love affair between Stahr and Thalia [Katheleen], an immediate, dynamic, unusual, physical love affair" (Bruccoli 410) can show another facet in Stahr's life and, of course, "this love affair is the meat of the book" (Bruccoli 410). In a flood, Stahr sees that "on top of a huge head of the god Siva, two women were floating down the current of an impromptu river" (26) and one of them has "the face of his dead wife, identical even to the expression" (26). "Across the four feet of moonlight the eyes he knew looked back at him, the curl blew a little on a familiar forehead, the smile lingered changed a little according to pattern, the lips parted-the same. An awful fear went over him and he wanted to cry aloud" (26). At this time, Stahr seems to lose his power and one just sees him as a poor husband who has lost his wife long ago. As Callahan points out, "Again we watch the division of manhood, strong and individual in the world, but weak and prosaic with a woman" (Callahan 209).

Evidently, Stahr seems to have been traumatized by the loss of his wife for a long time. According to Callahan, Gatsby, Diver, and Stahr "raise adolescent fantasy to the level of life's imperative. Internalized, the fantasies replace that American world to which they are similar but not identical in the first place" (Callahan 212). As can be seen from the novel, on his way back from the commissary and looking for a young actor and his girl, Stahr feels that "little by little he was losing the feel of such things, until it seemed that Minna had taken their poignancy with her; his apprehension of splendor was fading so that presently the luxury of eternal mourning would depart" (62). He tries desperately to meet Kathleen again, suggesting that he wants to meet his dead wife once more. Even though Stahr has a chance to talk with Kathleen, he still "felt a curious loneliness [...] It was the old hurt come back, heavy and delightful [...] he waited a moment, thinking of Minna. He explained to her that it was really nothing, that no one could ever be like she was, that he was sorry" (67). Stahr's psychological reaction exhibits that his repressed trauma is displayed not only through his memory but also through his actions. Dating a woman with much the same appearance as his dead wife cannot solve his depressive disorder.

For the first time since Minna's death, on the way to meet up with one of the women who resembles his wife, Stahr feels a "good illusion that it was a different moon every evening, every year. Other lights shone in Hollywood since 
Minna's death" (62). When Stahr sees Kathleen he thinks "it was Minna's face". At the moment of looking at Kathleen's eyes "they made love as no one ever dares to do after" (64). "Stahr does not idealize Kathleen. As it should, their union separates her from the images of Minna, Stahr's dead wife, images which only another woman could change from fixation to memory" (Callahan 208). After their first talk, Stahr has another chance to dance with Kathleen in the screenwriter's ball. According to the narrator, Kathleen "was deep in it with him [Stahr], no matter what the words were. Her eyes invited him to a romantic communion of unbelievable intensity" (73) and Stahr said "I don't want to lose you" (73). Furthermore, Kathleen realizes that "you've [Stahr] fallen for me - completely. You've got me in your dreams" (75). After Kathleen leaves the ball, Stahr asks Cecelia to dance. However, Cecelia feels "stabbing pain" because Kathleen "took the evening with her" (77) and "left the great ball-room empty and without emotion" (77). It seems to Cecelia that she "was dancing with an absent minded man" (77).

However, Kathleen is not the woman for Stahr. After a romantic night with him in his house by the beach, Kathleen says “I'm sorry I've been so mysterious - it was a compliment because I like you so much. You should try not to work so hard. You ought to marry again" (85). The letter which "was addressed to Monroe Stahr" that falls out of Kathleen's purse in Stahr's car reveals that Kathleen cannot ever become his love. In the letter, Kathleen has written "it is to tell you that I am to be married soon and that I won't be able to see you after today" (98). Stahr "was shocked by the letter's indifference to what had happened later" (98) and "he could not even believe this now and the whole adventure began to peel away even as he recapitulated it searchingly to himself" (99). For him "Minna died again on the first landing and he forgot her lingeringly and miserably again" (99). The fact, however, that Stahr "had never lost his head about Minna even in the beginning - it had been the most appropriate and regal match imaginable. She had loved him always and just before she died all unwilling and surprised his tenderness had burst and surged toward her and he had been in love with her. In love with Minna and death together - with the world into which she looked so alone that he wanted to go with her there" (97). Stahr's image of his dead wife now overlaps that of Kathleen Moore, the woman who has left him behind. Stahr, therefore, stands as a failure in private life. He seems not to recognize the importance of Kathleen's love for him, as he is so weakened by the loss of his wife. Stahr's past memory is too painful to acknowledge, so he can never find happiness with other women, even with one who has the same appearance as his dead wife.

We cannot leave The Love of the Last Tycoon without feeling disappointed that it was never completed. Despite the fact that the novel is an unfinished work, some critics declared that it was the best work that Fitzgerald produced. Stephen Vincent Benet commented that "Had Fitzgerald been permitted to finish the book, I think there is no doubt that it would have added a major character and a major novel to American fiction. As it is, 'The Last Tycoon' is a great deal more than a fragment. It shows the full powers of its author, at their height and at their best". Benet also wrote "You can take off your hats now, gentlemen, and I think perhaps you had better. This is not a legend, this is a reputation-and, seen in perspective, it may well be one of the most secure reputations of our time" (Bruccoli lxxvi). Obviously, the novel is the traumatic loss of Monroe Stahr, Fitzgerald's perfect and complete masculine hero, who seems doomed in the original plan of the novel. The brilliant tycoon is inevitably corrupted by the promised art and love that he wants to build in the "New World".

\section{References}

Addison, H. (2006). “'Must the Players Keep Young?’: Early Hollywood's Cult of Youth”. Cinema Journal, 45 (4), 3 25.

Berman, R. (2005). “American Dreams and 'Winter Dreams': Fitzgerald and Freudian Psychology in the 1920 s”. F. Scott Fitzgerald Review 4, 49-64.

Bruccoli, M. J. (2002). Some Sort of Epic Grandeur: The Life of F. Scott Fitzgerald. Columbia: University of South Carolina Press

(ed.) (1994). F. Scott Fitzgerald: A Life in Letters. New York: Scribner

Bryer, J. R, ed. (2000). F. Scott Fitzgerald: New Perspectives. Athens: University of Georgia Press

Callahan, J. F. (1996). 'F. Scott Fitzgerald's Evolving American Dream: The 'Pursuit of Happiness' in Gatsby, Tender is the Night and The Last Tycoon". Twentieth Century Literature 42

(1972). The Illusions of a Nation. Chicago: University of Illinois Press

Cullen, J. (2003).The American Dream: A Short History of an Idea that Shaped a Nation. Oxford: Oxford University Press

Fahey, W. A. (1973). F. Scott Fitzgerald and the American Dream. New York: Thomas Y. Crowell Company

Fitzgerald, F. Scott. (1993). The Love of the Last Tycoon: A Western. (ed.) Matthew J. Bruccoli. Cambridge University Press.

Latham, A. (1970). Crazy Sundays: F. Scott Fitzgerald in Hollywood. New York: Viking.

Pelzer, L. (2000). C. Student Companion to F. Scott Fitzgerald. Westport, Connecticut: Greenwood Press. 